\title{
Remote sensing for oil spill detection and response*
}

\author{
F. R. Engelhardt
}

ENOVA Research Applications, Orleans, ON, K1C 7A9, Canada

\section{INTRODUCTION}

Remote sensing is useful in several modes of oil spill control, including large area surveillance, site specific monitoring and tactical assistance in emergencies. Remote sensing is able to provide essential information to enhance strategic and tactical decision-making, potentially reducing incidence of spills by providing a deterrent factor, decreasing response costs by facilitating rapid oil recovery and ultimately minimising impact.

Marine oil spills can be separated into two categories of relevance to the type of remote sensing technology which might be used to detect and respond to the incident. A first category is nonaccidental discharges, which can include incidental losses from vessels due to hull or equipment leaks, as well as oil discharged intentionally during deballasting and tank-cleaning activities. While these nonaccidental discharges tend to be small in themselves, they are frequent and contribute much more to the overall introduction of oil to the marine environment than accidental spills, and are of increasing international regulatory concern. Accidental spills are much less frequent, but typically involves much larger releases of oil. Such oil spills are high profile events for which rapid and effective emergency response is needed to contain and recover the spilled oil. In many countries, an appropriate and effective response capability is required by law, such as demanded by the Oil Pollution Act of 1990 in the USA, as well as by recent amendments to the Canada Shipping Act in Canada. There is a growing recognition that using remote sensing, especially airborne, to aid cleanup response efforts can mitigate the effects of oil on the environment, as well as reduce cleanup costs.

Airborne remote sensing in the support of spill response operations has a mixed level of interest by spill responders when viewed globally. In the USA, for instance, airborne remote has had varying degrees of success in meeting operational expectations, and thus is not yet fully integrated into national, regional and area response plans and operations. By comparison, the record of successful use in the UK, for instance, is such that remote sensing support is contracted by the UK Coast Guard on a stand-by basis and used routinely when a significant spill occurs. As another example, airborne remote sensing technologies are now being adopted by the Australian Maritime Safety Authority to support its spill response actions.

Low altitude aircraft have proven to be the most effective tactical method for obtaining information about spills and assisting in spill response. Combined with accurate oil drift computer model forecasting, these two methods were the primary strategic tools used for environmental response planning during the IXTOC-1 and Arabian Gulf spills, although less useful for guiding tactical operations [1,2]. Conversely, essential tactical support was provided by aerial remote sensing for the application of dispersants, a major spill response in the Sea Empress spill in South-west Wales [3,4].

Currently, the use of imaging satellites for spill response is restricted because of limited spatial resolution, slow revisit times and often long delays in receipt of processed image data. The topic of oil spill monitoring by imaging satellites has been reviewed by Bern co-workers $[5,6]$. There are significant advances being made, however, to increase resolution and coverage, as well as in the speed of image

*Pure Appl. Chem. 71(1) (1999). An issue of special reports reviewing oil spill countermeasures. 
product delivery. Sensing oil on water by satellites appears best suited for routine surveillance purposes. There are synergisms in protecting the environment and property from oil spills which can be achieved by an integrated approach which draws on the remote sensing advantages of airborne and satellite imaging technology.

There are many potential users of such remote sensing information, in government and private sector organisations. Government authorities use such information in surveillance, for example in the North and Baltic Seas, detecting spills when they occur and for identification of the spiller, which could be a vessel discharging illegally. Many government organisations also maintain an organised oil spill response capability, which would be supported by remote sensing information in oil spill response operations. The private sector includes the primary oil industry operating globally, and oil transporters, which carry responsibility and potential liability in the event of a spill. Other potential users are oil spill response organisations which might offer a subcontracted remote sensing capability to their clients. Other private sector groups include the insurers for the shipping industry, who are directly and immediately interested in keeping both the costs of the response and oil spill impact damage as low as possible. The news media is a additional potential user, interested in quality graphical representation of the oil spill, as is true for any disaster event.

\section{SURVEILLANCE AND MONITORING}

Non-accidental discharges, whether from incidental undetected hull leaks or intentional through deballasting, are an area of acute regulatory concern. The incidence of such events is very high, and the volumes of oil introduced to the oceans is also considered significant, much exceeding that of accidental spills [7]. Another difference is that the source tends to be mobile, as compared to a stricken vessel which is more usually in a known location and stationary. There are many instances in North America and elsewhere, where marine wildlife losses, especially seabirds, have been attributed to incidental discharges of oil.

Surveillance and monitoring is viewed by many jurisdictions as an essential prevention and control measure. The issue forms a large part of the deliberations of the IMO Marine Environment Committee, and is regulated internationally through MarPol conventions and UNCLOS. It is one of the reasons for regular surveillance of the North Sea by remote sensing aircraft from all of the eight nations with exclusive economic zones in the North Sea, operating under the Bonn Agreement. The concern also provided an impetus for the oil spill detection use of the ERS-1 satellite, and now ERS-2, by the Norwegian Space Agency to establish an oil spill surveillance capability. This was developed starting in 1991 with multinational industry and government support, including that of the Marine Spill Response Corporation in the US. The development has become a functioning commercial enterprise managed by the Tromso Satellite Station. Satellite-based surveillance, assuming that the revisit times are adequate to meet the surveillance requirement (even if this is only partial), is generally perceived as more reasonable than maintaining constant surveillance using an airborne capability, whether commercial or government owned. Other countries, such as Australia, Canada, Chile and South Africa, are evaluating the benefit of implementing a satellite surveillance program for oil slick detection along their own extensive shorelines.

The essential elements to effective surveillance of nonaccidental discharges of oil include:

- Early identification of target anomaly and rapid verification;

- Delivery of alert warnings and image data in operational real time to allow interdiction;

- Image products tailored in their complexity to specific user information requirements;

- Image products compatible with and readily accessible to the software and hardware systems of the end user;

- Integrated data formats for multiple images;

- Compatibility and nonconflicting hand-over of surveillance image services to emergency response for interdiction or emergency response, and;

- Data security, safe data handling protocols and appropriate archiving. 
Several imaging radar satellites appear to be suitable, such as currently Radarsat, ERS-2, JERS-1, as well as others, to allow regular surveillance of marine oil discharges by vessels, or for that matter incidental or accidental discharges from oil platforms. A positive image from satellite data is not a guarantee that there is oil on the sea surface, but a reasonable probability, which is often followed up by scrambling a remote sensing aircraft for verification. The ability of an oil slick imaging system to provide also real-time sea state and weather information is invaluable in predicting the movement of the oil slick, to allow a better response planning and logistics, whether this is for oil containment and recovery or shoreline protection. Also, the more detailed and definitive image data provided by airborne systems assists in interdiction. Table 1 provides an overview of imaging satellites with proven and potential application in oil spill surveillance and monitoring. The radar satellites, where synthetic aperture radar

Table 1 Specifications of satellite surveillance systems potentially usable for oil spill detection

\begin{tabular}{|c|c|c|c|c|c|c|c|}
\hline Satellite-Sensor System & $\begin{array}{l}\text { Low Light/ } \\
\text { Night } \\
\text { Capability }\end{array}$ & $\begin{array}{l}\text { Cloud/Fog } \\
\text { Penetration } \\
\text { Ability }\end{array}$ & $\begin{array}{l}\text { Revisit Time } \\
\text { (Repeat } \\
\text { Coverage) }\end{array}$ & $\begin{array}{l}\text { Spatial } \\
\text { Resolu- } \\
\text { tion }\end{array}$ & $\begin{array}{l}\text { Swath } \\
\text { Width }\end{array}$ & $\begin{array}{l}\text { Data } \\
\text { Delivery } \\
\text { Time }\end{array}$ & $\begin{array}{l}\text { Phenomenon/ Feature } \\
\text { Detected }\end{array}$ \\
\hline $\begin{array}{l}\text { - SPOT 1, } 2 \text { and } 3 \text { : High } \\
\text { resolution visible (HRV) } \\
\text { imaging system, using multi- } \\
\text { spectral and panchromatic } \\
\text { modes }\end{array}$ & limited & no & $2-3 d$ to $26 d$ & $\begin{array}{l}\text { MS - 20m } \\
\text { Pan. - } \\
10 \mathrm{~m}\end{array}$ & $60-80 \mathrm{~km}$ & $\begin{array}{l}1-3 \text { weeks, } \\
\text { rush } 3-7 d\end{array}$ & $\begin{array}{l}\text { selective imaging of surface } \\
\text { features - oil spills, } \\
\text { vegetation cover, land use, } \\
\text { large scale erosion, } \\
\text { sedimentation plumes }\end{array}$ \\
\hline $\begin{array}{l}\text { - MOS-1, }-1 \mathrm{~b} \text { : visible and } \\
\text { thermal infrared radiometer } \\
\text { (VTIR), multi-spectral } \\
\text { electronic self-scanning } \\
\text { radiometer (MESSR), } \\
\text { microwave scanning } \\
\text { radiometer (MSR) }\end{array}$ & yes & yes & $17 d$ & $\begin{array}{l}\text { VTIR - } \\
0.9-2.7 \mathrm{~km} \\
\text { MESSR - } \\
50 \mathrm{~m} \\
\text { MSR - } \\
23-32 \mathrm{~km}\end{array}$ & $317 \mathrm{~km}$ & & $\begin{array}{l}\text { visible, IR and selective } \\
\text { spectral imaging of surface } \\
\text { features, oil spills, } \\
\text { temperatures, current } \\
\text { patterns }\end{array}$ \\
\hline $\begin{array}{l}- \text { NOAA-10 to }-14 \text { : } \\
\text { advanced very high } \\
\text { resolution radiometer } \\
\text { (AVHRR) }\end{array}$ & yes & yes & $8 \mathrm{~d}$ at equator & $1.1-4 \mathrm{~km}$ & $\begin{array}{l}\text { approx. } \\
3000 \mathrm{~km}\end{array}$ & weeks & $\begin{array}{l}\text { visible and IR imaging of } \\
\text { surface features, oil spills, } \\
\text { atmospheric sounding, } \\
\text { ozone measurement }\end{array}$ \\
\hline $\begin{array}{l}\text { - JERS-1: L-band SAR, } \\
\text { visible \& near infrared } \\
\text { radiometer (VNIR), } \\
\text { shortwave infrared } \\
\text { radiometer (SWIR) }\end{array}$ & yes & yes & $44 d$ & $\begin{array}{l}\text { SAR - } \\
18 \mathrm{~m} \\
\text { VNIR and } \\
\text { SWIR - } \\
18 \times 24 \mathrm{~m}\end{array}$ & $75 \mathrm{~km}$ & $\begin{array}{l}\text { more than } \\
4 \text { weeks }\end{array}$ & $\begin{array}{l}\text { high resolution of visible } \\
\text { and IR imagery, oil spills, } \\
\text { surface temperatures }\end{array}$ \\
\hline $\begin{array}{l}\text { - ERS-1, -2: C-band SAR } \\
\text { (image and wave modes), } \\
\text { SAR wind scatterometer, } \\
\text { radar altimeter, infrared } \\
\text { radiometer (IRR), } \\
\text { microwave sounder (MWS) }\end{array}$ & yes & yes & $\begin{array}{l}3-176 d \\
\text { majority of } \\
\text { time } 35 d\end{array}$ & $\begin{array}{l}\text { SAR - } \\
26-30 \mathrm{~m} \\
\text { Wind } \\
\text { scatterom } \\
-- \\
45+\mathrm{km} \\
\text { IRR - } \\
1-2 \mathrm{~km} \\
\text { MWS - } \\
20-22 \mathrm{~km}\end{array}$ & $\begin{array}{l}\text { SAR - } \\
100 \mathrm{~km} \\
\text { Wind } \\
\text { scatterom. } \\
500 \mathrm{~km} \\
\text { Radar } \\
\text { altimeter - } \\
20 \mathrm{~km} \\
\text { IRR - } \\
500 \mathrm{~km}\end{array}$ & $\begin{array}{l}\text { over } 4 \\
\text { weeks, } \\
\text { rush } 1-2 \mathrm{~d} \\
\text { or less }\end{array}$ & $\begin{array}{l}\text { ocean surface topography, } \\
\text { oil spills, wind and } \\
\text { temperature measurement, } \\
\text { vegetation cover, land use }\end{array}$ \\
\hline - Radarsat: C-band SAR & yes & yes & $1-3+d$ & $\begin{array}{l}10 \mathrm{~m} \text { and } \\
30 \mathrm{~m}\end{array}$ & $\begin{array}{l}50,100 \\
\text { and } 150 \mathrm{~km}\end{array}$ & $\begin{array}{l}1-5 d \text { or } \\
\text { less }\end{array}$ & $\begin{array}{l}\text { ocean surface topography } \\
\text { and ocean phenomena, oil } \\
\text { spills, vegetation cover, land } \\
\text { use }\end{array}$ \\
\hline $\begin{array}{l}\text { * - Earthwatch: Visible \& } \\
\text { near infrared (VNIR) }\end{array}$ & limited & no & $\begin{array}{l}\text { days to } \\
\text { months }\end{array}$ & high & narrow & $\begin{array}{l}1-3 \text { weeks, } \\
\text { rush } 3-7 d\end{array}$ & $\begin{array}{l}\text { high resolution visible and } \\
\text { IR imagery of surface } \\
\text { features, land cover, land } \\
\text { use change, water } \\
\text { pollutants }\end{array}$ \\
\hline $\begin{array}{l}\text { * - Eyeglass: Visible \& } \\
\text { near infrared (VNIR), steroe } \\
\text { capability }\end{array}$ & limited & no & $\begin{array}{l}\max \text {. less } \\
\text { than } 2 d\end{array}$ & $1 \mathrm{~m}$ & $15 \mathrm{~km}$ & $2 \mathrm{~d}$ or less & $\begin{array}{l}\text { high resolution visible and } \\
\text { IR imagery of surface } \\
\text { features, land cover, land } \\
\text { use change, water } \\
\text { pollutants }\end{array}$ \\
\hline $\begin{array}{l}\text { * Landsat 7: High spatial } \\
\text { resolution visible and } \\
\text { infrared imagery }\end{array}$ & yes & yes & & high & narrow & & $\begin{array}{l}\text { land surface features, oil } \\
\text { spills, vegetation cover, land } \\
\text { use }\end{array}$ \\
\hline
\end{tabular}

*Not yet in commercial operation. 
(SAR) images dampening of capillary waves on the sea surface caused by even thin layers of oil, appear to have the greatest current utility for oil slick imaging. There are high expectations in place about the ability of the next generation of high resolution commercial satellites to image oil on the sea surface.

Aside from monitoring the introduction of oils into the seas, spill information is also considered as an indicator of other pollution events. Specifically, the concern is that nonindigenous marine organism might be introduced into receiving waters by deballasting, putting indigenous marine species at risk, similar to the introduction of the zebra mussel into waters of the Great Lakes. This is of concern in Alaska, as one example, where the issue draws strong attention from state government regulators as well as the US Coast Guard. It needs to be considered as an emerging issue at this point, but might be a useful added benefit to regular marine surveillance.

\section{EMERGENCY RESPONSE}

A major difference between the more tactical emergency response as compared to surveillance and routine monitoring is the obvious inability to schedule the remote sensing activity in emergencies. Tactical response to an oil spill emergency has a number of unique requirements relevant to the selection of a remote sensing approach, most of which would only be addressed through the airborne systems:

- The remote sensing service must be quickly available to benefit from early response actions;

- Need for a real-time data output, of medium level resolution;

- High level of location accuracy is required;

- Day-night service useful, at least to gather spill information before daylight response operations;

- Multiple users of information are active at the same time during the response, who want:

- an unambiguous format for tactical response operations, targeted on the essentials of the response parameters,

- more complex information sets for the planning stages of emergency response,

-attractive graphic information for news reporting of the event;

- Data management equipment needs to be commonly available, portable, rugged and hold high user confidence;

- Requirement for image information to be part of response operation plans and procedures through a well integrated training program;

- Image information to be accessible to forward command units, such as by electronic linkage to portable PC computers;

- Ability to easily integrate image data from other sources, such as satellites;

- Ability to integrate remote sensing image data with other information sources, such as geographic information system (GIS) databases; and,

- Insurance and legal issues require a rigorous record of the event, one which would have testimonial value, and needs to be archived appropriately for claims adjudication.

It is common practice to discuss the airborne remote sensing asset as a system, roughly composed of a platform, sensors, data processors and communications. The system is made up of some to all of the following:

- Platform, which might be fixed wing or rotary wing aircraft, or lighter-than-air craft;

- Sensor(s), which may be viewed singly or integrated and image-fused;

- Data storage (film, tape, disc, CD);

- Avionics and aircraft attitude sensors;

- Geolocation devices (GPS, INS);

- Sensor integrating computers; 
- Image processing computers;

- Communications and data links to ground (may be via communications satellite); and,

- Ground stations, both mobile and stationary.

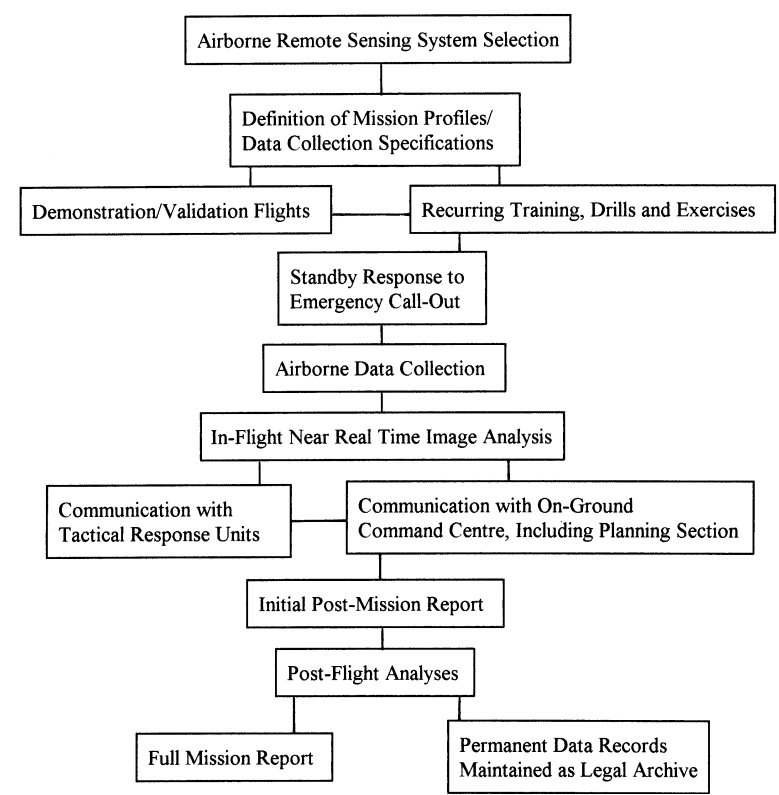

Fig. 1 Integrated sensing in oil spill emergency response operations.

Figure 1 provides a flow-chart of how remote sensing information is used in oil spill response planning and countermeasures operations. In addition, from the responsible party's and insurers' perspective, the cost-effectiveness of integrating remote sensing into oil spill response has also been demonstrated (unpublished report by H. Manetti to the Marine Spill Response Corporation 1994). Further, operationally real time remote sensing of oil slicks might allow mapping anticipated impact areas in advance of contact with the drifting slick. Such information would not only be useful for the operational response planning team, but would also provide a real-time, preimpact baseline record of sensitive areas of which are threatened by the incident. Such preimpact measurements can prove invaluable in rehabilitation management, as well for damage and liability assessment, of interest to responsible parties, insurers and plaintiffs.

A diversity of sensor systems have been used successfully on aircraft, based on different electrophysical principles of action. Table 2 provides an broad overview of sensor systems considered operational, with an adequate record of use to provide confidence of the ability of the sensors to image oil and assist the countermeasures operation. The information provided for airborne sensors in Table 2 shows that their detection ability extends beyond oil spill applications. These data are purposely included here, as a point of guidance, since practical experience has shown that airborne remote sensing operations are unlikely to remain financially viable if they limit themselves to only oil spill detection and response. Alternative complementary uses appear to be essential. For additional reference, Fingas \& Brown $[8,9]$ have also written reviews of oil spill remote sensors and provided an opinion on future trends.

An example of breakthrough technology in airborne remote sensing for oil spills was achieved by the US-based Marine Spill Response Corporation. A new airborne remote sensing platform, known as the Baseline Remote Sensing System (BRSS) was completed in 1994 as part of MSRC's R\&D program $[10,11]$. The BRSS was designed for two purposes: as a proof of concept for a more economical, higher capability airborne surveillance system and as a research test bed able to apply its sensor and image integration capacity for further remote sensing system development. The BRSS moved away from the concept of complex independent sensor systems carried in large expensive airframes. Its development was based on integrated, multisensor arrays with a common high capacity processor, able to provide realtime image products to end users, while remaining portable enough to fit into small aircraft. Its capability 
Table 2 Specifications of airborne remote sensing systems suitable for oil spill detection and monitoring, and supplemental actions

\begin{tabular}{|c|c|c|c|c|c|c|c|c|}
\hline Sensor System & $\begin{array}{l}\text { Low Light/ } \\
\text { Night } \\
\text { Capability }\end{array}$ & $\begin{array}{l}\text { Cloud/Fog } \\
\text { Penetration } \\
\text { Ability }\end{array}$ & $\begin{array}{l}\text { Rain } \\
\text { Interference }\end{array}$ & $\begin{array}{l}\text { Data Output } \\
\text { Format }\end{array}$ & $\begin{array}{l}\text { Geo- } \\
\text { coding }\end{array}$ & $\begin{array}{l}\text { Spatial } \\
\text { Resolu- } \\
\text { tion * }\end{array}$ & $\begin{array}{l}\text { Width/ } \\
\text { Image } \\
\text { Area * }\end{array}$ & $\begin{array}{l}\text { Phenomenon/ Feature } \\
\text { Detected }\end{array}$ \\
\hline $\begin{array}{l}\text { Conventional still } \\
\text { camera } \\
\text { - panchromatic/ } \\
\text { còlour }\end{array}$ & limited & no & somewhat & film/print & no & $\mathrm{cm}+$ & $\begin{array}{l}100 \mathrm{~m} / \\
\text { sq.km+ }\end{array}$ & $\begin{array}{l}\text { panchromatic/colour rendition } \\
\text { of features in visible spectrum - } \\
\text { thick oil spicks, vegetation } \\
\text { patterns, land use, erosion } \\
\text { patterns, surface waters, } \\
\text { bottom features, sedimentation }\end{array}$ \\
\hline $\begin{array}{l}\text { - infrared } \\
\text { - ultraviolet }\end{array}$ & yes & limited & $\begin{array}{l}\text { somewhat } \\
\text { somewhat }\end{array}$ & $\begin{array}{l}\text { film/print } \\
\text { film/process } \\
\text { ed print }\end{array}$ & no & $\mathrm{cm+}$ & $\begin{array}{l}100 \mathrm{~m} / \\
\text { sq.km+ } \\
100 \mathrm{~m} / \\
\text { sq.km+ }\end{array}$ & $\begin{array}{l}\text { near infrared rendition of } \\
\text { features - thick oil spicks, } \\
\text { vegetation and moisture; } \\
\text { albedo related } \\
\text { UV rendition of features - thin } \\
\text { oil sheens on water, stressed } \\
\text { vegetation }\end{array}$ \\
\hline $\begin{array}{l}\text { Conventional or } \\
\text { enhanced video } \\
\text { camera }\end{array}$ & low light & no & somewhat & video tape & no & $\mathrm{dm}+$ & $\begin{array}{l}100 \mathrm{~m} / \\
\text { sq.km+ }\end{array}$ & $\begin{array}{l}\text { panchromatic/colour rendition } \\
\text { of features in visible spectrum - } \\
\text { thick oil slicks, vegetation } \\
\text { patterns, land use, erosion } \\
\text { patterns, surface waters, some } \\
\text { bottom features, sedimentation }\end{array}$ \\
\hline Digital still camera & limited & no & somewhat & $\begin{array}{l}\text { digital disc } \\
\text { or tape }\end{array}$ & yes & $\mathrm{cm}+$ & $\begin{array}{l}100 \mathrm{~m} / \\
\text { sq.km+ }\end{array}$ & $\begin{array}{l}\text { panchromatic/color rendition of } \\
\text { features in visible spectrum - } \\
\text { thick oil slicks, vegetation } \\
\text { patterns, land use, erosion } \\
\text { patterns, surface waters, some } \\
\text { bottom features, sedimentation }\end{array}$ \\
\hline Digital video camera & low light & no & somewhat & digital tape & yes & $\mathrm{dm}+$ & $\begin{array}{l}100 \mathrm{~m} / \\
\text { sq.km+ }\end{array}$ & $\begin{array}{l}\text { panchromatic/colour rendition } \\
\text { of features in visible spectrum - } \\
\text { thick oil slicks, vegetation } \\
\text { patterns, land use, erosion } \\
\text { patterns, surface waters, some } \\
\text { bottom features, sedimentation }\end{array}$ \\
\hline Multispectral camera & limited & no & yes & $\begin{array}{l}\text { digital disc } \\
\text { or tape }\end{array}$ & yes & $\mathrm{dm}+$ & $\begin{array}{l}100+\mathrm{m} / \\
\text { sq.km+ }\end{array}$ & $\begin{array}{l}\text { small number of selected } \\
\text { spectral bands for enhanced } \\
\text { feature specificity -oil sheens, } \\
\text { ocean color, vegetation types } \\
\text { and characteristics }\end{array}$ \\
\hline UV sensor & no & no & yes & $\begin{array}{l}\text { digital disc } \\
\text { or tape/ } \\
\text { video tape }\end{array}$ & yes & $\mathrm{dm}+$ & $\begin{array}{l}20 \mathrm{~m}+1 \\
\text { sq. } \mathrm{km}+\end{array}$ & $\begin{array}{l}\text { UV rendition of features - oil } \\
\text { sheens on water, stressed } \\
\text { vegetation }\end{array}$ \\
\hline $\begin{array}{l}\text { Near IR }(3-8 \mathrm{~nm}) \\
\text { sensor }\end{array}$ & yes & minimal & yes & $\begin{array}{l}\text { digital disc } \\
\text { or tape/ } \\
\text { video tape }\end{array}$ & yes & $m+$ & $\begin{array}{l}20 m+1 \\
\text { sq.km+ }\end{array}$ & $\begin{array}{l}\text { IR rendition of features - oil on } \\
\text { water, stressed vegetation, soil } \\
\text { erosion }\end{array}$ \\
\hline
\end{tabular}

*Function of operating altitude of aircraft.

has been demonstrated in several settings, experimental to validate image products and in actual oil spill response operations. The success of the basic design of the BRSS has provided a stimulus and model for a number of other system manufacturers to build and use multisensor systems for oil spill response.

\section{INTEGRATION OF SATELLITE AND AIRBORNE IMAGING}

In many instances, integration of space borne and airborne data sources would be of benefit. An integrated remote sensing system could quickly provide accurate location information for the oil slick, identifying both the total area of the slick and also the boundary of the thicker layers of oil, and communicate the response-relevant information to ground and sea stations in near real-time. Such a system would be more likely to generate information on a reliable basis in daylight or night-time and under adverse weather 
Table 2 continued

\begin{tabular}{|c|c|c|c|c|c|c|c|c|}
\hline Sensor System & $\begin{array}{l}\text { Low Light/ } \\
\text { Night } \\
\text { Capability }\end{array}$ & $\begin{array}{l}\text { Cloud/Fog } \\
\text { Penetration } \\
\text { Ability }\end{array}$ & $\begin{array}{l}\text { Rain } \\
\text { Interference }\end{array}$ & $\begin{array}{l}\text { Data Output } \\
\text { Format }\end{array}$ & $\begin{array}{l}\text { Geo- } \\
\text { coding }\end{array}$ & $\begin{array}{l}\text { Spatial } \\
\text { Resolu- } \\
\text { tion * }\end{array}$ & $\begin{array}{l}\text { Width/ } \\
\text { Image } \\
\text { Area * }\end{array}$ & $\begin{array}{l}\text { Phenomenon/ Feature } \\
\text { Detected }\end{array}$ \\
\hline $\begin{array}{l}\text { Far/thermal IR (8-13 } \\
n m) \text { sensor }\end{array}$ & yes & somewhat & sómewhat & $\begin{array}{l}\text { digital disc } \\
\text { or tape/ } \\
\text { video tape }\end{array}$ & yes & $d m+$ & $\begin{array}{l}10 \mathrm{m+l} \\
\text { sq.km+ }\end{array}$ & $\begin{array}{l}\text { IR rendition of features - thick } \\
\text { oil on water, shallow sub- } \\
\text { surface oil contamination, } \\
\text { shallow sub-surface water, } \\
\text { buried objects, vegetation and } \\
\text { land use, surface } \\
\text { temperatures, current } \\
\text { sirculation patterns, animals } \\
\text { and people }\end{array}$ \\
\hline $\begin{array}{l}\text { Multi-spectral } \\
\text { scanning system }\end{array}$ & limited & poor & yes & $\begin{array}{l}\text { digital disc } \\
\text { or tape }\end{array}$ & yes & $\mathrm{dm}+$ & $\begin{array}{l}100 \mathrm{~m} / \\
\mathrm{sq} . \mathrm{km}+\end{array}$ & $\begin{array}{l}\text { selective multiple-wavelength } \\
\text { rendition - oil slicks and } \\
\text { sheens, vegetation types and } \\
\text { stress, land use, erosion, } \\
\text { bottom features, susp. } \\
\text { sediment, chlorophyll, current } \\
\text { patterns, wave spectra }\end{array}$ \\
\hline $\begin{array}{l}\text { Hyper-spectral } \\
\text { scanning system }\end{array}$ & possible & possible & yes & $\begin{array}{l}\text { digital disc } \\
\text { or tape }\end{array}$ & yes & $\mathrm{dm}+$ & $\begin{array}{l}100 \mathrm{~m} / \\
\text { sq.km+ }\end{array}$ & $\begin{array}{l}\text { selective multiple-wavelength } \\
\text { rendition - oil slicks and } \\
\text { sheens, vegetation types and } \\
\text { stress, selected plant species, } \\
\text { land use, erosion, soil types, } \\
\text { bottom features, susp. } \\
\text { sediment, chlorophyll, current } \\
\text { patterns, wave spectra, } \\
\text { surface temperature patterns }\end{array}$ \\
\hline $\begin{array}{l}\text { Microwave } \\
\text { radiometer }\end{array}$ & yes & yes & minimal & $\begin{array}{l}\text { digital disc } \\
\text { or tape }\end{array}$ & yes & $20-40 m$ & $\begin{array}{l}\mathrm{km} / \\
\mathrm{sq} \cdot \mathrm{km}+\end{array}$ & $\begin{array}{l}\text { oil slicks, surface } \\
\text { temperatures, water salinity, } \\
\text { surface winds }\end{array}$ \\
\hline Laser fluorosensor & yes & no & yes & $\begin{array}{l}\text { digital disc } \\
\text { or tape }\end{array}$ & yes & $m+$ & $\begin{array}{l}50- \\
100 \mathrm{~m} / \\
\text { sq.km+ }\end{array}$ & $\begin{array}{l}\text { oil and chemical slicks, gases, } \\
\text { chlorophyll }\end{array}$ \\
\hline $\begin{array}{l}\text { Imaging radar - side- } \\
\text { looking airborne radar } \\
\text { (SLAR) }\end{array}$ & yes & yes & minimal & $\begin{array}{l}\text { digital disc } \\
\text { or tape }\end{array}$ & (yes) & $m+$ & $\begin{array}{l}20-40 \mathrm{~km} / \\
100 \text { 's sq. } \\
\mathrm{km}\end{array}$ & $\begin{array}{l}\text { oil slicks, vegetation and land } \\
\text { use, erosion patterns, current } \\
\text { circulation patterns, wave } \\
\text { spectra, topography }\end{array}$ \\
\hline $\begin{array}{l}\text { Imaging radar - } \\
\text { synthetic aperture } \\
\text { radar (SAR) }\end{array}$ & yes & yes & minimal & $\begin{array}{l}\text { digital disc } \\
\text { or tape }\end{array}$ & (yes) & $0.5-m+$ & $\begin{array}{l}\text { few to } \\
\text { many } \\
\mathrm{km} / \\
\text { many } \\
\text { sq.km }\end{array}$ & $\begin{array}{l}\text { oil slicks, vegetation and land } \\
\text { use, erosion patterns, current } \\
\text { circulation patterns, wave } \\
\text { spectra, topography }\end{array}$ \\
\hline
\end{tabular}

conditions. Linkage to several image data sources provides not only system redundancy and potential backup if one or another source becomes not available, but is also complementary in providing both widearea and site-specific detail information, possibly integrated into a single image product. Such capabilities would be considered essential for interdiction purposes, to identify a discharging vessel, and needed by spill responders.

The flow chart of Fig. 2 provides a model of how satellite and airborne remote sensing capabilities might usefully be integrated in emergency response operations. This suggested approach will become particularly relevant once image services and products from the upcoming lower cost, high resolution satellites can be accessed by the commercial market.

\section{CONCLUSIONS}

The opportunities for airborne platforms have also improved due to more capable sensors, both smaller and less costly, similarly new image processing technology, so that information at a spill site can be provided rapidly with the precision and accuracy needed for both tactical operations and strategic planning. The integration of advanced image processing technology, multiple or multiwavelength sensors, accurate geographic positioning devices, and avionics, allows more effective spill imaging. 


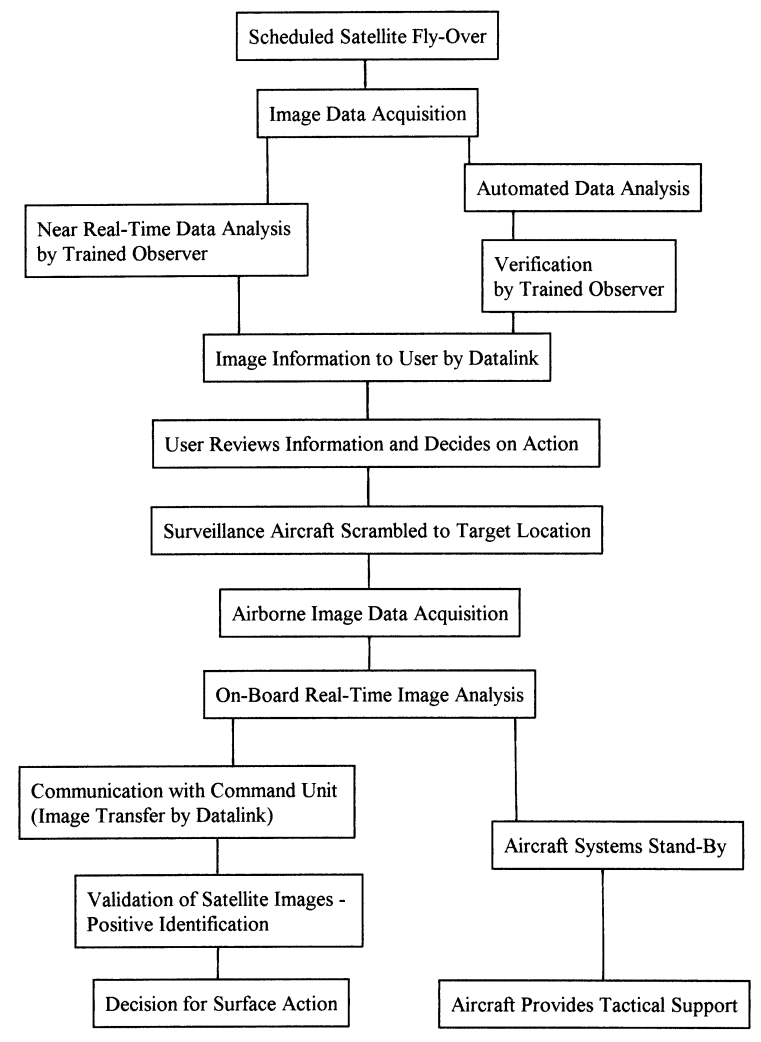

Fig. 2 Integrated satellite-airborne remote sensing (ISARS).

Previous limitations, usually describing only the general size and approximate location of a patch of oil, are being removed, allowing quantitative information about the physical aspects of an entire spill, an understanding of its behaviour over time within the environment surrounding the spill, and a timerelevant assessment of the effectiveness of countermeasures as they are being deployed. Notwithstanding the current tactical limitations of using satellite remote sensing in spill response, imaging satellites are a useful element of spill detection, and should be integrated into spill surveillance and response action plans, complementary to the more operational use of aircraft remote sensing platforms.

\section{REFERENCES}

1 R. Pavia, D. L. Payton. An approach to observing oil at sea. In Proceedings of the 1983 Oil Spill Conference, 28 February-3 March, pp. 345-349. San Antonio, TX (1983).

2 H. M. Cekirge, A. H. Al-Rebeh, N. Gunay. Use of three generations of oil spill models during the Gulf War oil spills. In Proceedings of the 15th Arctic and Marine Oil Spill Program (AMOP) Technical Seminar, 10-12 June, pp. 93-106. Edmonton, Canada (1992).

3 C. Harris. The Sea Empress incident: overview and response at sea. In Proceedings of the 1997 International Oil Spill Conference, pp. 177-184. Ft. Lauderdale, FL (1997).

4 T. Lunel, L. Davies, S. Shimwell, V. Byfield, S. Boxall, C. Gurney. Review of aerial/satellite remote sensing carried out at the Sea Empress incident. In Proceedings of the Third International Airborne Remote Sensing Conference 1997, pp. I-731-I-732. Copenhagen (1997).

5 T.-I. Bern Oil spill detection: documentation of historical remote sensing projects and status. Marine Spill Response Corporation, Washington, DC Technical Report Series 93-004 (1993).

6 T.-I. Bern, T. Wahl, T. Anderson, R. Olsen. Oil spill detection using satellite based SAR. Experience from a field experiment. Photogrammetric Engineering Remote Sensing 59(3), 423-428 (1993).

7 National Research Council. Oil in the Sea. National Academy of Sciences, Washington, DC (1985). 
8 M. F. Fingas, C. E. Brown. A review of oil spill remote sensors. In Proceedings of the Third International Airborne Remote Sensing Conference 1997, pp. I-707-I-714, Copenhagen (1997).

9 M. F. Fingas, C. E. Brown. Airborne oil spill remote sensors-do they have a future? In Proceedings of the Third International Airborne Remote Sensing Conference 1997, pp. I-715-I-722, Copenhagen (1997).

10 C. P. Giammona, K. S. Binkley, F. R. Engelhardt, J. D. Nichols, S. Buechel. Enhanced spill response using new airborne multisensor and image processing technology. In Proceedings of the Second International Oil Spill Research Development Forum 1995, pp. 566-576. London, UK (1995).

11 R. A. Lambert, J. A. Schell, C. P. Giammona, K. S. Binkley. Airborne surveillance technology options for improving oil spill cleanup and response. Marine Spill Response Corporation, Washington, DC. MSRC Technical Report Series 92-m2 (1992). 